\title{
Performance of Electronic Components Exports in India
}

\author{
G. V. Vijayasri \\ Assistant Professor, Department of Economics, \\ AKNU MSN Campus, Kakinada, Andhra Pradesh, India.
}

CITATION: Vijayasri, G. V. (2020), "Performance of Electronic Components Exports in India", MERC Global's International Journal of Management, Vol. 8, Issue 3, pp. 133-138.

ARTICLE HISTORY: Submitted: April 12, 2020, Revision received: May 16, 2020, Accepted: May 30,2020

\section{ARTICLE TYPE: Review paper}

\begin{abstract}
Electronics Components exports have been widely studied. It also examined the trends in Electronics Component production, Changes in the direction of Electronics Components Exports and also studies the export of top items, major companies exporting Electronics Components. EU countries remain the top destination of Electronics Components during the year 2017-18. Part of Transformers has emerged to be the top item during the year 2017-18. It has been observed that the Electronics Components sector not only contributes significantly to export earnings and GDP, but also emerges as a major source of employment generation in the country. Though the Electronics Components sector in India is small at present, there are several advantages which India can effectively leverage to achieve higher growth. This article discusses the current performance of electronic components exports in India.
\end{abstract}

KEYWORDS: Electronics components, Exports, Production, Destination, Items, Companies.

\section{BIBLIOGRAPHY}

1. "Economic Survey" (2018-19), Government of India.

2. "Electronics and Software Export Promotion Council (ESC)", Statistical Yearbook, different Years.

3. A Brief Report on "Electronics Industry in India", Corporate Catalyst India, August 2012.

4. Dadas, Anand B. and Kumar, Atul (2017), "A Study on Critical Equipment Element Maintenance Services Requirements in Distillery Industry", MERC Global's International Journal of Social Science \& Management, Vol. 4, Issue 4: November, pp. 116-121.

5. Kadam, Sameer (2014), "Information Resources about Electronic Components", International Journal of Engineering Research \& Technology, Vol. 3, Issue 8, pp. 1431-1436.

6. Sinha, Shaili (2016), "Globalization and its Impact on Electronics Industry in India", Rai Management Journal, Vol. XIII, Issue 1, pp. 59-65. 